\title{
Evaluation of the Anti Chagas "PF" Vaccine Against two Strains of Leishmania sp. in Hamsters (*)
}

\author{
Jorge R. Arias ("*) \\ Humberto Menezes ( $\# *$ ) \\ Rui A. de Freitas (**)
}

\begin{abstract}
Amastigotes of two strains of Leishmania sp. were innoculated into golden hamsters (Mesocrice. tus auratus) 8 and 15 days after innoculation with the anti-chagas "PF" vaccine. There was no significant difference in reduction of infection between the "PF" treated and the control (untreated) hamsters after innoculations with either strain of Leishmania sp.
\end{abstract}

\section{INTRODUCTION}

The origin and activity of the anti-chagas "PF" vaccine has been thoroughly discussed by Menezes (1969a, b, 1970, 1972a, b, 1974, 1975) and will not be covered here.

This experiment was suggested by Prof. Warwick E. Kerr, and its main purpose was to find whether or not the "PF" vaccine would delay the activity of Leishmania sp. in hamsters.

\section{METHODS AND MATERIALS}

Eighty golden hamsters (Mesocricetus auratus) were randomly placed in 8 groups of 10 each. Later, 2 of these groups of 10 were divided in half, becoming 4 groups of 5 each.

One of the groups of 10 hamsters was maintained untreated to serve as the control (C). The remaining 5 groups of 10 hamsters were innoculated subdermally with the "PF" vaccine. Of these, one group was not treated further and became the "PF" control (PF). Two of the remaining 4 groups of 10 hamsters were innoculated subdermally, in the nose, with amastigotes of each of the 2 strains of Leishmania sp. 8 days after the "PF" treatment,
$(\mathrm{PF}+8+\mathrm{LA})$ and $(\mathrm{PF}+8+\mathrm{LJ})$ respectively. The remaining 2 groups of 10 hamsters were similarly innoculated with both strains of Leishmania sp. 15 days after the "PF" treatment, (PF + $15+\mathrm{LA})$ and $(\mathrm{PF}+15+$ LJ) respectively.

The 4 groups of 5 hamsters each were innoculated with of the strains of Leishmania $\mathrm{sp}$. at the same time as those mentioned above, to serve as Leishmania controls (to insure infectivity of the tissue triturate which was used as the infective agent). These were $(8+$ LA $),(8+L J),(15+L A)$ and $(15+L J)$ respectively.

The "PF" vaccine used, and method of preparation, was the same as described in Menezes (1975). The vaccine was prepared fron: the 400 th passage of the "PF" Trypanosome cruzi strain maintained in culture media as described by Warren (1960) for 27 days. The final suspension contained about $50 \%$ motile trypanosomes and almost 5\% were metacyclic forms. All hamsters, whose mean weghi was $35 \mathrm{gms}$, were innoculated subdermally with approximately $3.9 \times 10^{5}$ motile parasites.

The origin of the Leishmania sp. Strain $\mathrm{J}$ is that of a 31-year-old male patient who manifested over 50 verrucose papilomas varying in diameter from 0.2 to $3.0 \mathrm{~cm}$ over his entıre body. Innoculation into a hamster's nose produces an initial small verrucose growth at site of innoculation, approximately one to two months after infection. This wart remains for $1-2$ weeks when it either drops off and typical Leishmania manifestations follow, or it gradu ally becomes a typical lesion.

( * ) - This project was partly supported by the CNPq Grant SIP/08-131.

(*) - Department of Medical Sciences, Instituto Nacional de Pesquisas da Amazônia, Manaus.

(…) - Department of Genetics, School of Medicine, Ribeirão Preto, SP . 
This parasite develops relatively rapidly in hamsters. Hamsters innoculated with this strain develop histiocytomatas in the feet within 3 months after innoculation. For this reason, we believe that the parasite belongs to the Leishmania mexicana complex, as defined by Lainson and Shaw (1973).

The origin of the Leishmania sp. Strain A is of a 41 year-old female patient with diffuse leishmaniasis. It is being maintained in our laboratory due to its rapid growth and high virulence. Its rapid development in hamsters, as well as its metastization in the hamsters' feet, suggests it also belongs to the L. mexicana complex (Lainson and Shaw 1973).

The amastigotes used in this experiment were obtained from tissue triturates of biopsies of leishmania lesions from infected hamster noses and were maserated in a mortar with a pestle with $2 \mathrm{ml}$ of physiological saline. Small quantities of this triturate were innoculated subdermally into the noses of the test hamsters.

A hamster was recorded as "positive" when a definite warty growth or lesion on the nose developed. Persistance of the lesion and future metastization in the hamsters' extremities were also observed.

\section{RESUlts}

This experiment was terminated 150 days after innoculation with the respective Leishmania sp. No change in results had been noticed during the final 75 days, and only three hamsters which had previously been considered "suspicious" became "positive" after the 7 th week post vaccination (Table 1).

As can be seen in Table 1, none of those hamsters which were maintained untreated and served as the controls (C), nor those innoculated with the "PF" vaccine alone (PF), became infected. One hundred percent of all hamsters innoculated with Strain A became "positive"; not only those solely innoculated with Strain A, but also those innoculated with the "PF" vaccine 8 and 15 days previously. Strain J showed itself to be much less virulent, only infecting $62.5 \%$ of innoculated hamsters.

It is interesting to observe that with every "PF" treatment there is a slight delay of Leishmania infectivity in the hamsters, as compared to the same treatment without the "PF" vaccine. This delay, however, may be due to the fewer number of treatments in the groups without the "PF" treatment.

TABLE 1. - N.० of hamsters which became positive with leishmaniasis after various treatments.

\begin{tabular}{|c|c|c|c|c|c|c|c|c|c|c|c|c|c|c|c|}
\hline \multirow{2}{*}{ Treatment (1) } & \multicolumn{11}{|c|}{ Weeks post-treatment } & \multicolumn{2}{|c|}{ N. 0} & \multirow{2}{*}{$\%$ Pos. } & \multirow{2}{*}{$\begin{array}{c}\bar{X} \text { N. Weeks } \\
\text { to become } \\
\text { pos. }\end{array}$} \\
\hline & 1 & 2 & 3 & 4 & 5 & 6 & 7 & 8 & 9 & 10 & 11 & Treat. & Pos. & & \\
\hline G & - & - & - & - & - & - & - & - & - & - & - & 10 & 0 & 0 & $\rightarrow$ \\
\hline PF & - & - & - & - & - & - & - & - & - & - & - & 10 & 0 & 0 & $\rightarrow$ \\
\hline $8+$ LA & - & - & - & - & 1 & 4 & - & - & - & - & - & 5 & 5 & 100 & 5.8 \\
\hline $\mathrm{PF}+8+\mathrm{LA}$ & - & - & - & 2 & 2 & 3 & 2 & - & - & 1 & - & 10 & 10 & 100 & 6.0 \\
\hline $15+\mathrm{LA}$ & - & 一 & - & 一 & 5 & - & - & - & - & - & - & 5 & 5 & 100 & 5.0 \\
\hline $\mathrm{PF}+15+\mathrm{LA}$ & - & - & - & - & 4 & 4 & 2 & - & - & - & - & 10 & 10 & 100 & 5.8 \\
\hline $8+\mathrm{LJ}$ & - & - & - & 1 & 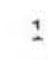 & 1 & - & - & - & - & - & 5 & 3 & 60 & 5.0 \\
\hline $\mathrm{PF}+8+\mathrm{LJ}$ & - & - & - & - & 5 & 2 & - & 1 & - & - & 1 & 10 & 9 & 90 & 6.2 \\
\hline $15+\mathrm{LJ}$ & - & - & 一 & 3 & 一 & 一 & - & - & - & - & - & 5 & 3 & 60 & 4.0 \\
\hline $\mathrm{PF}+15+\mathrm{LJ}$ & - & - & - & - & 2 & 2 & - & - & - & - & - & 10 & 4 & 40 & 5,5 \\
\hline
\end{tabular}

(1) - See text for abbreviations. 


\section{Conclusions}

Hamsters were utilized because of their intensive use as a laboratory tool in Leishmania studies. The "PF" vaccine as an antileishmanial vaccine is far from being adequate. Another vaccine produced from Leishmania parasites may suggest an avenue of attack to the high incidence of leishmaniasis in the Central Amazon region.

\section{SUMÁrIo}

A vacina antichagásica "PF" foi testada em hamsters contra duas cepas de Leishmania. Os animais vacinados com a cepa PF foram desafiadas 8 e 15 dias mais tarde com estas duas cepas de Leishmania. Após o término da experiência, i. e. 150 dias após inoculação, notou-se que a vacina "PF" não tinha efeito protetor contra Leishmania, em hamsters. Os leves aumentos do tempo de la tência nos animais vacinados, sugerem que possivelmente uma vacina seja a arma para controlar a alta incidência desta doença na Amazônia Central.

\section{LITERATURE CITED}

Lainson, R. \& Shaw, J.J.

1973 - Leishmanias and Leishmaniasis of the new world, with particular reference to Brazil. Bull. P.A.H.O., 7(4) : 1-19.

MENEZES, $\mathrm{H}$.

1969a - Active immunization of dogs with a non-virulent strain of Trypanosoma cruzi. Rev. Inst. Med. Trop. São Paulo, 11(4) : 258-263.

$1969 \mathrm{~b}$ - Active immunization of mice with the avirulent $\mathrm{Y}$ strain of Trypanosoma cruzi against heterologous virulent strains of the same parasite. Rev. Inst. Med. Trop. São Paulo, 11(5) : 335-342.

1970 - Imunização de camundongos com "vacina" viva avirulenta de Trypanosoma cruzi IV. Ensaio de esquema de "vacinação". Rev. Soc. Bras. Med. Trop., 4 : 158-166.

1972a - Imunização ativa contra a Trypanosomose americana. Medicina. Rev. do CARL e do HC da Fac. Med. Rib. Preto - USP, $5: 85-93$.

$1972 \mathrm{~b}$ - The avirulence of the cultivated $\mathrm{Y}$ strain of Trypanosoma cruzi IV. The effects of immusuppressive agents in mice. Rev. Soc. Bras. Med. Trop., 5(4) : 213-233.

1974 - The avirulence of the cultivated PF strain of Trypanosoma cruzi IV - The effect of antilimphocytic serum in dogs. Rev. Soc. Med. Trop., 7(5):253-265.

1975 - The un-infectivity of the PF cultivated strain of Trypanosoma cruzi to mice. An evaluation through a one year period by blood cultures and histopathology. Rev. Soc. Bras. Med Trop., 9(1) : 1-9.

WARREN, L.G.

1960 - Metabolism of Schizotrypanum cruzi, Chagas I - Effect of culture age and substrate concentration on respiratory rate. J. Parasitol., $46: 529-539$. 